\title{
Mucosal leishmaniasis
}

\author{
Leishmaniose mucosa
}

\section{José Roberto Lambertucci', René Coulaud ${ }^{1}$ and Luciana Cristina dos Santos Silva ${ }^{1}$}

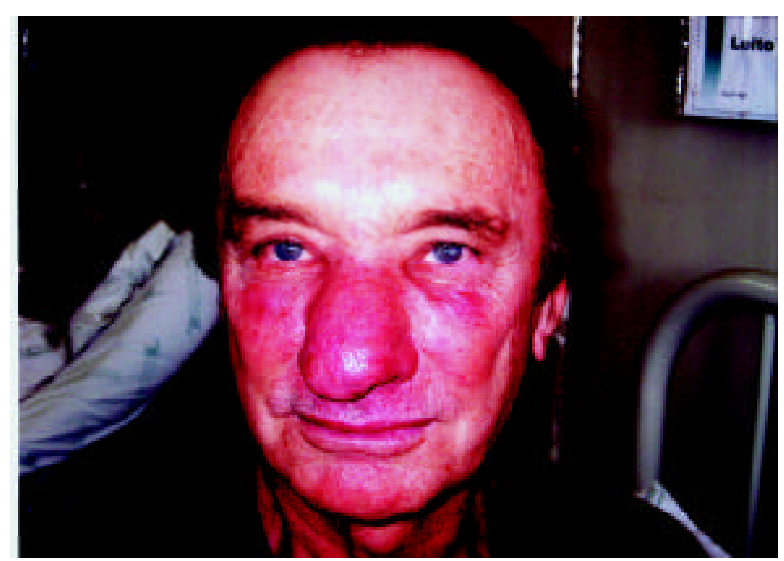

A

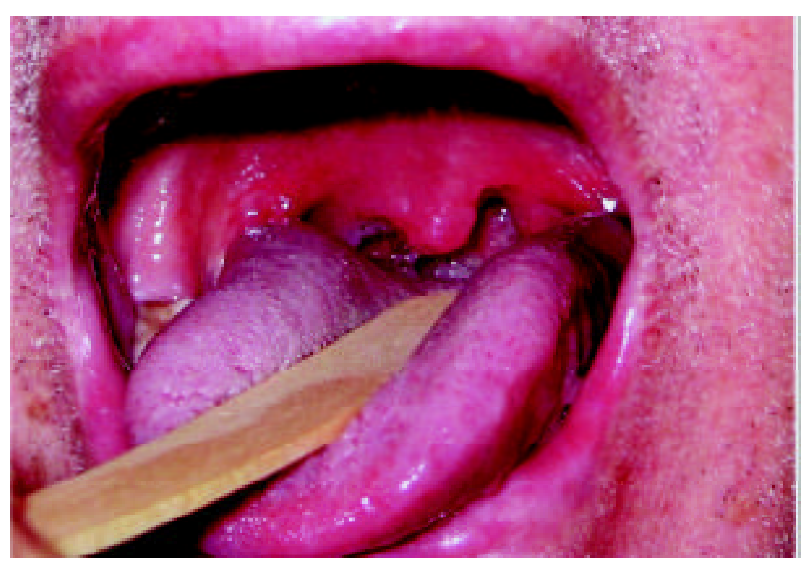

B

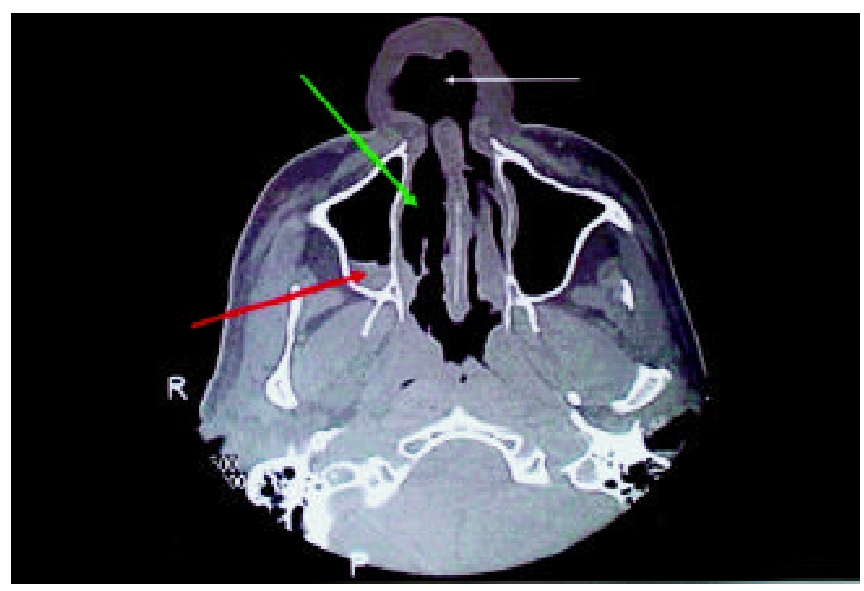

C

1. Departamento de Clínica Médica, Serviço de Doenças Infecciosas e Parasitárias da Faculdade de Medicina da Universidade Federal de Minas Gerais, Belo Horizonte, MG.

Address to: Prof. José Roberto Lambertucci. Faculdade de Medicina/UFMG. Avenida Alfredo Balena 190, 30130-100 Belo Horizonte, MG.

e-mail: lamber@net.em.com.br

Received 15 April 2003. 
A 64 years old man was admitted to hospital complaining that for the last 4 years he has been annoyed by this increase in the size of his nose associated with erythema (Figure A), edema and local discomfort. He also noticed progressive destruction of the nasal septum and nasal discharge of purulent and bloody secretion. With time, there was involvement of the uvula (Figure B); he presented difficulty in swallowing and eventually was unable to eat or drink. There was a $10 \mathrm{~kg}$ weight loss over the last 6 months. He visited doctors and hospitals, and on many occasions was treated with different drugs, but with no avail. He was submitted to 4 biopsies of the mucosa of the nose; the first 2 suggested the diagnosis of tuberculosis and he was unsuccessfully treated with rifampin, isoniazid and pyrazinamide for six months. The other 2 biopsies showed nonspecific findings. He was also treated for paracoccidioidomycosis (with negative immunodiffusion and immunofluorescent tests) with ketoconazol for 6 months without improvement. The leishmanin test resulted negative but the indirect fluorescent antibody test for leishmaniasis was positive. Figure C tomographic scan of the sinuses shows a collection of liquid on the right maxillary sinus (red arrow), a complete destruction of the septum (white arrow) and a disruption of the nasal conchae (green arrow). Treatment was started with glucantime - meglumine antimoniate (20 $\mathrm{mg} \mathrm{Sb} / \mathrm{Kg}$ body weight/day) for 7 days followed by clarithromycin ( $1 \mathrm{~g} /$ day, divided in two oral doses) for 7 days. The cycle was repeated 4 times, completing 8 weeks of treatment. There was great improvement. He started to eat and drink, the edema and inflammatory signs decreased greatly and at the end of the treatment there was no more discharge of secretion from the nose. $\mathrm{He}$ is still being followed up at the outpatient clinic, waiting the proper time for surgical intervention on his nose.
O paciente de 64 anos de idade procurou o hospital com queixa de aumento do tamanho do nariz, com edema, eritema (Figura $A$ ) e desconforto de início há quatro anos. Ele também notou destruição do septo nasal e a descarga periódica de secreção purulenta e/ou sanguinolenta. Com o tempo observou envolvimento do palato mole e úvula (Figura B). Havia dificuldade inicial à deglutição que evoluiu com a impossibilidade de ingerir alimentos sólidos e líquidos. Nos últimos seis meses perdeu $10 \mathrm{~kg}$ de peso corporal. Visitou médicos e hospitais e recebeu tratamento com medicamentos variados sem obter melhora. Submeteu-se a quatro biópsias de mucosa nasal: as duas primeiras sugeriam o diagnóstico de tuberculose e por isso foi tratado, sem sucesso, com rifampicina, isoniazida e pirazinamida, por seis meses; as outras duas biópsias mostraram infiltrado inflamatório inespecífico e ele foi tratado para paracoccicioidomicose (testes de imunodifusão e de imunofluorescência negativos) com cetoconazol por seis meses, sem obter melhora. Submeteu-se ao teste intradérmico (reação de Montenegro) com resultado negativo. A sorologia para leishmaniose (reação de imunofluorescência indireta) mostrou-se positiva em título de 1:80. Na Figura $C$ veja a tomografia de seios da face que mostra a presença de líquido no seio maxilar direito (seta vermelha), a destruição do septo nasal (seta branca) e dos cornetos à direita (seta verde). Ele foi tratado com glucantime - antimoniato de meglumina ( $20 \mathrm{mg} \mathrm{Sb} / \mathrm{kg}$ de peso/dia) durante sete dias, seguido de claritromicina ( $1 \mathrm{~g} /$ dia, dividido em duas tomadas orais) por sete dias. Este esquema foi repetido quatro vezes, completando oito semanas de tratamento. Houve grande melhora clínica. Ele voltou a se alimentar, houve desaparecimento do edema e da descarga de secreções nasais e diminuição acentuada do eritema. O paciente continua sendo acompanhado em ambulatório à espera do momento oportuno para submeterse à cirurgia reparadora da lesão nasal.

\section{REFERENCES}

1. Marsden PD. Pentavalent antimonials: old drug for new diseases. Revista da Sociedade Brasileira de Medicina Tropical 18: 187-198, 1985.

2. Prata A, Silva-Vergara ML, Costa L, Rocha A, Krolewecki A, Silva JC, Paula EV, Pimenta, FG, Ramirez LE. Eficácia da azitromicina no tratamento da leishmaniose tegumentar americana. Revista da Sociedade Brasileira de Medicina Tropical 34 (supl III): 133, 2001.
3. Sampaio RNR, Paula CDR, Sampaio JHD, Furtado RS, Leal PP, Rosa TT, Rodrigues ME, Veiga JPR. Avaliação da tolerância e nefrotoxicidade do antimonial pentavalente administrado na dose de $40 \mathrm{mg} \mathrm{sb} / \mathrm{kg} / \mathrm{dia}$, de $12 / 12 \mathrm{~h}$, por 30 dias na forma cutâneo-mucosa de leishmaniose. Revista da Sociedade Brasileira de Medicina Tropical 30: 457-463, 1997. 